\title{
Foreign Demand on Land in Africa: Some Thoughts on Decision-making in the Central African Sub-region
}

\author{
Ernest L. Molua ${ }^{1} \&$ Lamourdia Thiombiano ${ }^{2}$ \\ ${ }^{1}$ Department of Agricultural Economics and Agribusiness, Faculty of Agriculture \& Veterinary Medicine, \\ University of Buea, Cameroon \\ ${ }^{2}$ Food and Agriculture Organization of the United Nations (UN FAO), Sub-regional Office for West Africa, \\ Accra, Ghana \\ Correspondence: Ernest L. Molua, Department of Agricultural Economics and Agribusiness, Faculty of \\ Agriculture \& Veterinary Medicine, University of Buea, Cameroon. E-mail: emolua@cidrcam.org
}

Received: June 28, 2014 Accepted: November 13, 2014 Online Published: January 22, 2015

doi:10.5539/jsd.v8n1p44 URL: http://dx.doi.org/10.5539/jsd.v8n1p44

\begin{abstract}
In line with colonial land grabs, there has been recent surge on land acquisition particularly in countries in Central Africa having suitable land available. While the form and substance of the large-scale land acquisitions vary across countries, rancorous debates have pondered whether this is an opportunity to develop Africa and ensure food security, or that the risks of large-scale land acquisition are very negative on local communities than the opportunities they bring. The goal of this paper is therefore to examine large-scale land investments in Africa particularly in countries within the Congo Basin Forest of the Central African sub-region. The trends, threats and opportunities are reviewed using information on land acquisitions in Central Africa collated from diverse published sources. The paper recommends some practical considerations for the sub-region to accommodate land acquisition.
\end{abstract}

Keywords: foreign land acquisition, agricultural performance, central African sub-region

\section{Background}

Africa is characterized by large amount of arable land which is estimated to be $26.5 \%$ of its total land mass (UNEP, 2008). With increasing population and growing industrial base the need of land for agricultural activities has been increasing to meet the demand for food and inputs in the food processing industry. Figure 1 note that agricultural production in Africa has witnessed a steady increase across all the sub-regions. Southern Africa and Central Africa have been growing at much higher and increasing rates. However, since 2000 North Africa and West Africa have experienced increased production relative to the 1960s and 70s. Higher population growth rates and the greater responsiveness of demand to income growth, the response of the agricultural sector have steadily increased for nearly all the main agricultural commodities. However, in per capita terms, production levels still remain below those of rapidly emerging economies. This, nonetheless, highlights the potential of Africa's agricultural sector and the need to consolidate its share in global production and trade. 


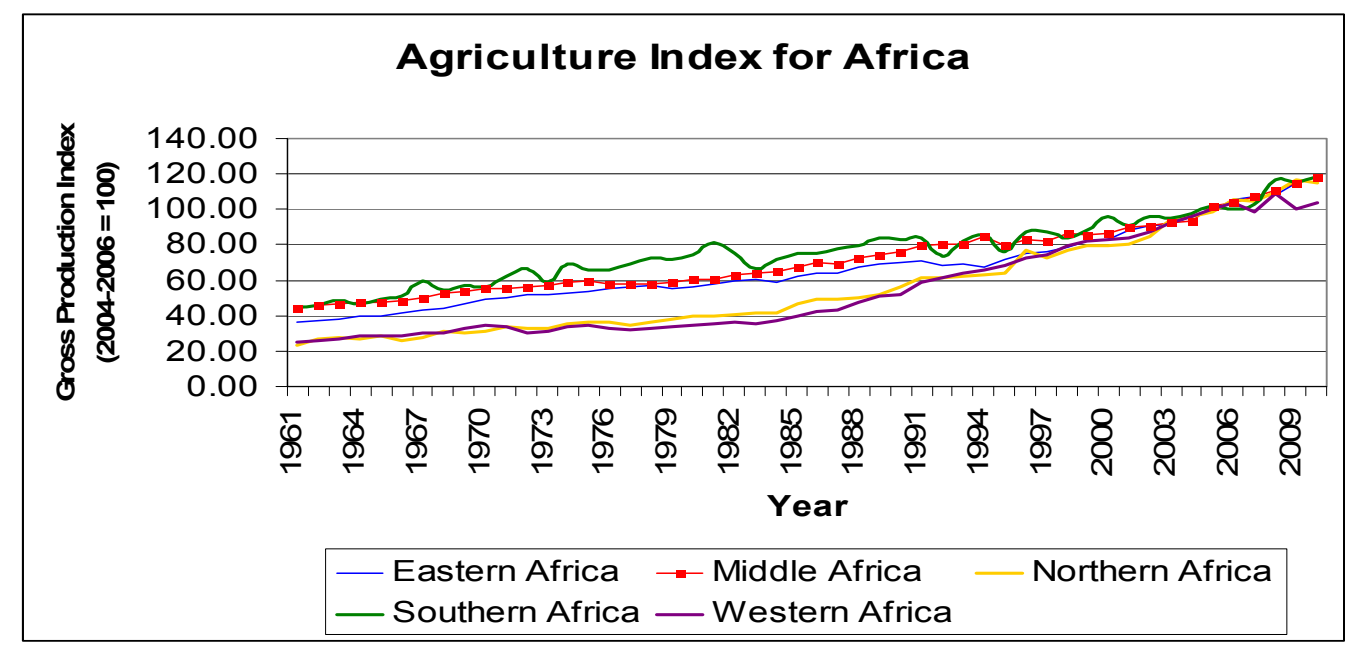

Figure 1. Agricultural production trends in Africa (Authors' construction from FAOSTAT)

For countries in central Africa, agriculture has been the Achilles heel to their development. Not only are countries in Central Africa significantly endowed with natural resources within the continent, agriculture's significant contribution to the gross domestic product (GDP) of the sub-region could be better. In the last decade Central Africa has led economic growth in Africa fuelled by oil production, with Chad and Equatorial Guinea recording the fastest growth in the continent. However, Central Africa is a net importer of food overwhelmed by production challenges including land degradation and climatic variation.

The decreasing access to productive land and the threats from competition by large multinationals on fertile land has compounded the agricultural production challenge (Tamrat, 2010; Araghi, 1995). Primarily the fear of food insecurity following the 2007-08 food price spikes promoted land grabs through widespread corporate investment in food crops in the region (Zoomers, 2010). Figure 2 depicts trends of global food price index between 1990 and 2012. (Note 1) Global food prices peaked in 2006 and remained high and volatile even though declines were observed in 2011 and 2012. Slow growth in crop production and expansion in food demand have tightened global food, principally due to declining value of the U.S. dollar, rising energy prices, increasing agricultural costs of production, adverse weather conditions and steps taken by some countries to curb their food exports to mitigate their own food price inflation (World Bank, 2011). Cameroon, Gabon and other countries in the subregion were among countries that experienced significant increases in food prices since 2008 (FAO, 2009). Although not new, overall investment levels for land have increased in the past ten years, with new expansions in South America and sub-Saharan Africa, particularly in countries having suitable land available with low land costs. (Note 2) The form and substance of such large-scale land acquisitions vary across countries (Arezki et al., 2011; Matondi et al., 2011; Tamrat, 2010).

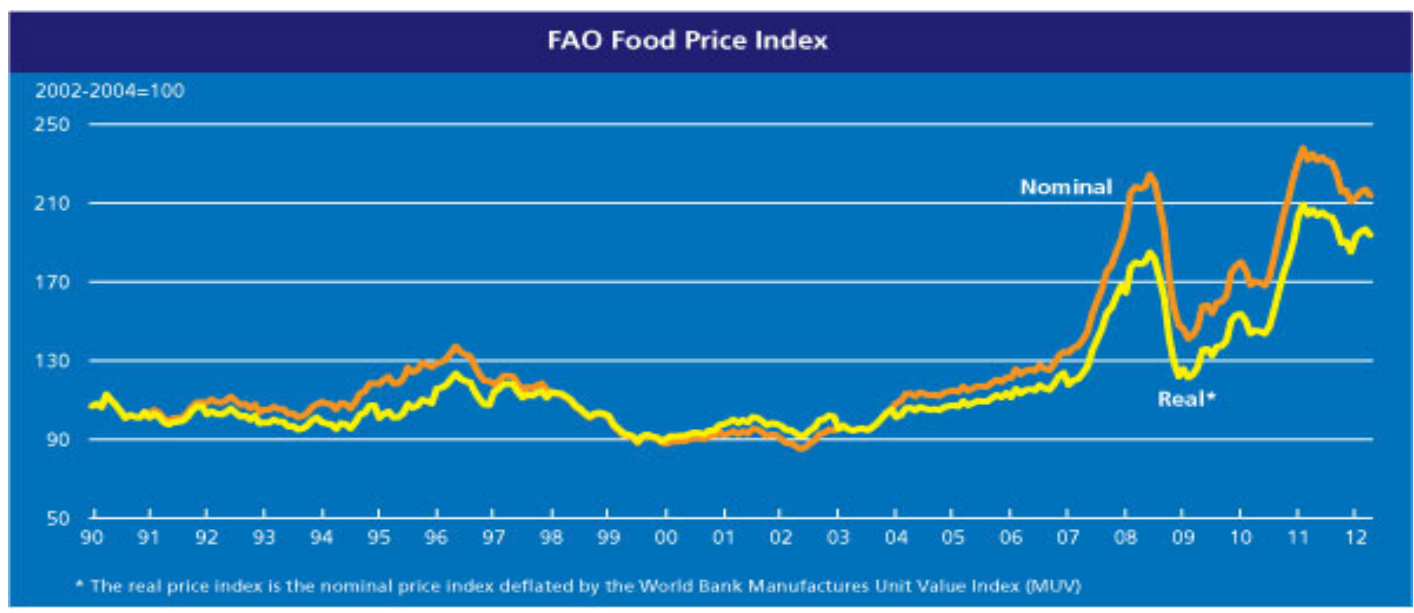

Figure 2. Food price trends (Source: FAO, 2012) 
Rancorous debates have pondered whether land investments is an opportunity to development for Africa and a way to secure food needs of their people, or that the risks associated with large scale land acquisition are very negative on the local community than the development they bring (Robertson \& Pinstrup-Anderson, 2010; Assies, 2009; Araghi, 1995). It is in this context that this paper examines large-scale land acquisitions in Africa particularly in countries within the Congo Basin Forest of the Central African subregion. In addressing this objective, section two lays out the context in more detail on the trends, threats and opportunities in the preliminary data on several large-scale land acquisitions in Central Africa. Section three provides policy instrument to support land investments for better agricultural performance. The paper concludes with a number of practical considerations for the subregion to take into account moving forward.

\section{Foreign Land Acquisition: Trends, Threats and Opportunities (Note 3)}

In Africa, the practice of acquiring large tracts of land dates from the colonial era (Bernstein 1996), with cropland plantations, e.g. Malawi (tobacco), Ghana (wood), Ivory Coast, Cameroon and Central African Republic (rubber, oil palm, banana, etc.). Since 1922, over 50,000 ha of oil palm plantations in the Democratic Republic of Congo, and by 1930 rubber plantations were established in Liberia by the Firestone Company. Figure 3 shows that, very recently, a total of $21,855,243$ ha of land has been allocated to private investors or foreign government constituting approximately $2.7 \%$ of arable land in Africa, with about 120 operations underway in 21 African countries for producing food crops (corn, wheat, rice, cassava, sweet potatoes, Cash crops: flowers (roses), soybeans, alpha alpha, vegetable crops, sweet sorghum), plantation crops (tea, oil palm, jatropha, sugar cane), livestock (cattle, chickens), aquaculture and for carbon storage (i.e. maintaining forest landscape). Of these, a total of 13,238,000 ha is allocated to five main partners (estimated to be more than $50 \%$ of continental allocation), for three key commodities: cereals (rice), tubers (cassava) and plantation crops (oil palm). There is particular emphasis on oil palm plantations perhaps for biofuels and consumption, across the countries implicated (Matondi et al., 2011).

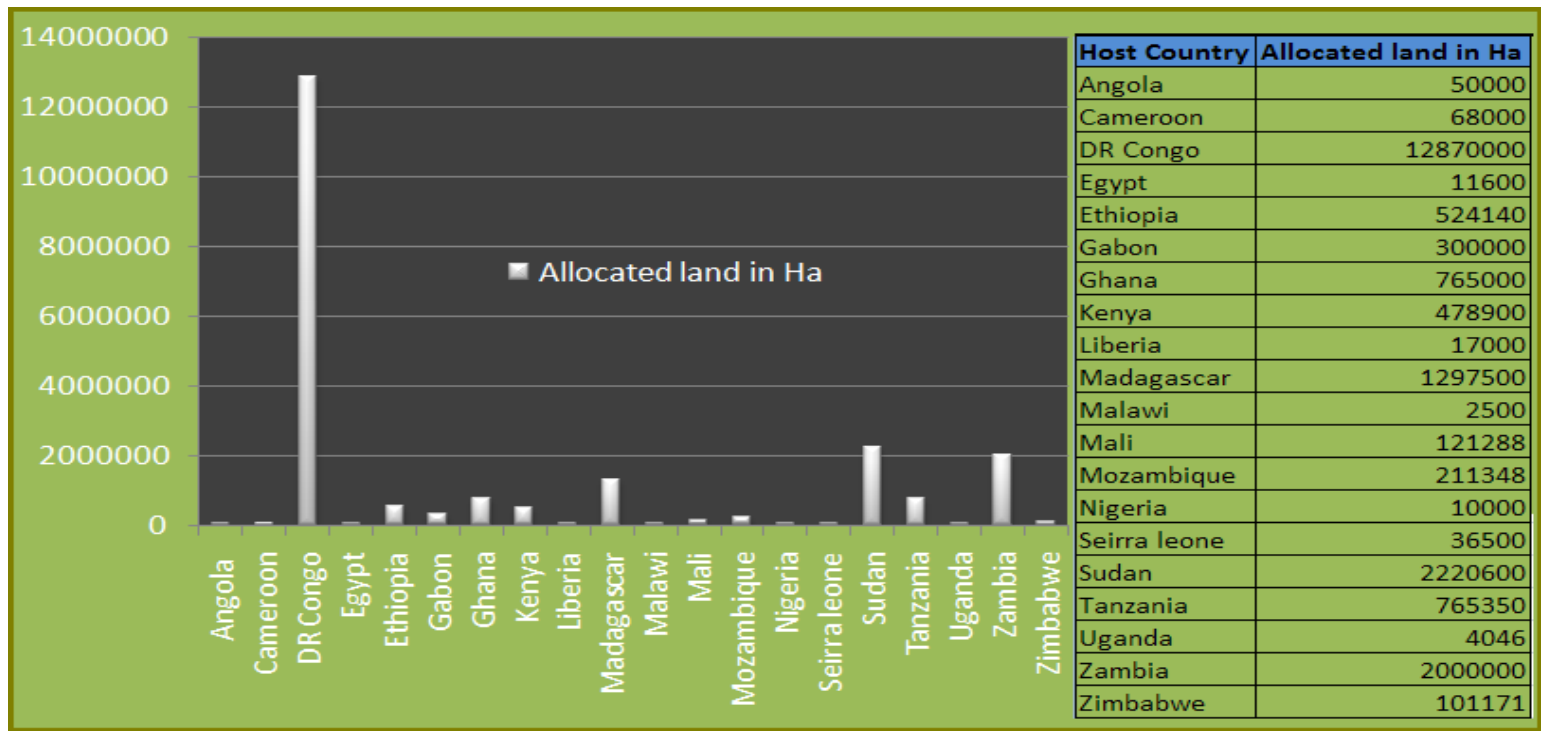

Figure 3. Land allocated to foreign investors in selected African countries(Source: Authors' construction)

Friis and Reenberg (2010) in a joint research project for land systems for the International Geosphere-Biosphere Programme and the International Human Dimensions Programme were able to show a cluster of land deals in the Democratic Republic of Congo as well as in countries like Ethiopia, Mozambique, Uganda, Madagascar, Sudan and Mali. As shown in table 1 below, they estimate that the land deals represent more than $5 \%$ of the current agricultural area - in Uganda more than 14\%, in Mozambique more than $21 \%$ and in DR Congo more than $48 \%$ of the agricultural land. This may have consequences for the local population and environment, with impacts such as agricultural intensification, forest degradation, displacement of local populations, increasing local food insecurity and increasing poverty. According to Jägerskog et al (2011) the investments range from small to large scale, and run through small-holders sharecropping or tenancy. The investors comprise of international corporations, sovereign wealth funds, foreign governments, private equity firms and domestic actors (Miller et al., 2010; Zoomers, 2010; Arezki et al., 2011). While land acquisitions by domestic investors are also significant, 
foreign investment accounts for the bulk of land deals. Large-scale land acquisitions and grabs have long been a prominent feature of African development and European colonial expansion overseas and the development of absolutist states within Europe (Benton \& Straumann, 2010). According to Makki and Geisler (2011), European expansion overseas were historically related processes and their overall effect was to expand the productive base of capitalism, which meant that land could now be marketed for "higher use." This historical catalyst for African land grab is being emulated by emerging economic giants of China and Brazil (Alemu \& Scoones, 2013; Hofman \& Ho, 2012; Bräutigam \& Tang, 2009).

Table 1. Land resources and land deals in Africa

\begin{tabular}{lllllll}
\hline \multirow{2}{*}{$\begin{array}{l}\text { Recipient } \\
\text { country }\end{array}$} & \multicolumn{3}{l}{ FAO land resource data (1,000ha) } & \multicolumn{3}{l}{ Land deals as percentage of: } \\
\cline { 2 - 7 } & $\begin{array}{l}\text { Land } \\
\text { area }\end{array}$ & $\begin{array}{l}\text { Agricultural } \\
\text { area }\end{array}$ & Forest & $\begin{array}{l}\text { Land } \\
\text { area }\end{array}$ & $\begin{array}{l}\text { Agricultural } \\
\text { area }\end{array}$ & $\begin{array}{l}\text { Agriculture }+ \\
\text { forest }\end{array}$ \\
\hline Ethiopia & 100.000 & 35.077 & 12.718 & 2,9 & 8,2 & 6,1 \\
Madagascar & 58.154 & 40.843 & 12.764 & 4,7 & 6,7 & 5,1 \\
Sudan & 237.600 & 136.773 & 66.368 & 1,3 & 2,3 & 1,6 \\
Tanzania & 88.580 & 34.200 & 34.433 & 1,9 & 5,0 & 2,5 \\
Mali & 122.019 & 39.619 & 12.372 & 2,0 & 6,1 & 4,6 \\
Mozambique & 78.638 & 48.800 & 19.162 & 13,1 & 21,1 & 15,2 \\
Uganda & 19.710 & 12.812 & 3.454 & 9,5 & 14,6 & 11,5 \\
DR Congo & 226.705 & 22.650 & 132.971 & 4,9 & 48,8 & 7,1 \\
Nigeria & 91.077 & 78.500 & 10.270 & 0,9 & 1,0 & 0,9 \\
Zambia & 74.339 & 25.589 & 41.562 & 3,0 & 8,8 & 3,3 \\
Ghana & 22.754 & 14.850 & 5.286 & 0,4 & 0,6 & 0,4 \\
Malawi & 9.408 & 4.970 & 3.336 & 3,3 & 6,2 & 3,7 \\
Senegal & 19.253 & 8.637 & 8.583 & 2,6 & 5,9 & 3,0 \\
\hline
\end{tabular}

Source: Friis and Reenberg, 2010

While foreign land acquisition is not a recent phenomenon, however, the current context is characterized by the advent of growing population, competition for land use, increased attention to good governance, flow of information, confidentiality and increased focus on potential risks to the environment (Robertson and Pinstrup-Anderson 2010; Bernstein 1996). In the recent times, Cotula and Vermeulen (2009) note a cumulative increase in land investment. The World Bank study of large-scale land acquisitions entitled 'Rising Global Interest in Farmland,' shows an inventory of land transfers from 2004-09 in fourteen countries. According to the Bank, "compared to an average annual expansion of global agricultural land of less than 4 million hectares before 2008, approximately 56 million hectares worth of large-scale farmland deals were announced even before the end of 2009," with over 70 percent of the large-scale land deals in Africa (World Bank 2010). Chinese land investors in the DRC, the Republic of Congo and Cameroon are at various stages of commitment either for mining or other land-intensive investments (Hofman \& Ho, 2012; Bräutigam, 2009). Bräutigam and Zhang (2013) note growing role for Chinese investors in Africa, whether state-owned or private, in promoting agricultural investment for commercial import substitution of rice, wheat, maize and vegetables, as well as industrial inputs and biofuel exports such as sisal, sugar and oil palm.

The expressed demand for land has focused disproportionately on Africa, where two-thirds of such demand is concentrated and where demand in 2009 alone was equivalent to more than 20 years of previous land expansion (Deininger, 2011). The recent years have seen an upward trend in both project numbers and allocated land areas. Further growth is anticipated (Cotula, 2012; Lavers, 2012). Bräutigam and Zhang (2013) suggest that Chinese agricultural investment in Africa will increase. However, these acquisitions are taking place through new mechanisms of accumulation that threaten to re-work land and resource access throughout the region. Not only is the phenomenon occurring, the size of single acquisitions can be very large too. Cotula and Vermeulen (2009) observed that in July 2009 the government of Ethiopia marked out 1.6 million ha of land, extendable to 2.7 
million, for investors willing to develop commercial farms. Other allocations include a 452,500ha biofuel project in Madagascar, a 150,000ha livestock project in Ethiopia and a 100,000ha irrigation project in Mali. According to our assessment, a lot of land deals took place in this decade than ever before. A total of eighty five land deals were registered in sixteen countries. The smallest and largest land holdings were 1,600 ha and 10,000,000 ha in Egypt and Democratic Republic of Congo, respectively. Information on the size of land was obtained for forty three deals which sum to $21,517,412$ ha which is $2.6 \%$ of the total cultivable land of Africa. According to the size of land given for investors, the Democratic Republic of Congo (12,800,000 ha) recorded the largest land surrendered followed by Zambia (2,000,000 ha) and Sudan (1,405,600 ha).

These land deals involved governments and private sector investors. Private sector deals account for about 90 per cent of allocated land areas. Government-owned investments make up the remainder. Nunow (2011) examined the various land deals in the Kenya's Tana Delta and the actors involved, and notes that even a government agency and the largest sugar company in Kenya have converted about 40,000 ha of the delta into a monoculture sugar cane plantation. Nunow identified other land deals of significant concern within the delta and its immediate neighborhood to include: Bedford Bio-fuels Inc, a privately held multinational company based in Canada, to acquire 90,000 ha of land through 45-year lease agreement, to grow jatropha curcas; Tiomin Kenya Ltd, a company incorporated in Canada, to mine titanium in the delta; another sugar company, Mat International, to acquire 120,000 ha of land in Tana delta and adjacent districts, and Qatar intends to lease from the Kenya government about 40,000 ha of land in delta to grow food crops, in exchange for supporting a major new port in nearby Lamu town.

In the case of Ethiopia, for instance, Makki and Geisler (2011) note that the "investors that have so far come forward are a mix of states and private agro-industrial complexes. They include three Indian companies which were awarded land in the Gambella region of southwestern Ethiopia. Another Saudi company was given "10,000 hectares to grow rice for the Saudi market, but this is set to expand to as much as 100,000 ha in the near future." They further reported smaller scale investments by Israeli, Dutch, German, Italian, and Chinese firms interested in biofuels or grain production. According to Makki and Geisler (2011) "the effect has been a steady secular increase in total FDI inflows into Ethiopia over the past decade, increasing from US\$ $135 \mathrm{~m}$ in 2000 to US\$ $545 \mathrm{~m}$ in 2004, and since then the yearly FDI inflows have varied between US\$ $545 \mathrm{~m}$ and US\$ $265 \mathrm{~m}$."

Why the interest on sub-Saharan Africa? According to Jägerskog et al (2012), Cotula (2011) and Hawkins (2010) there are some key reasons of the investment interest being directed towards tropical areas in general and SSA in particular. These regions feature relative abundance of water and land resources, inexpensive labour and very low land prices. For example, in Brazil or Argentina land prices are on average $\$ 5,000$ US per ha per year. In Ethiopia and Liberia, lands are leased for \$5 US per ha per year (Cotula, 2011). The interest in agricultural land investments is driven by investors' attempt to balance risks and returns with farmland investments seen as opportunity for high long-term returns. High returns may come from a combination of rising farmland values and increased agricultural productivity on acquired land (Hawkins 2010). Such returns to land are significantly influenced by export and domestic prices of agricultural commodities. In addition, good conditions for growing biofuel crops are found in the tropics, where crops like sugarcane, sorghum and jatropha that produce little Carbon dioxide emissions can be grown.

According to Wourtese (2012) farmland acquisitions may be associated with both opportunities and risks. Opportunity in that they may enhance agricultural productivity through increased capital investments and infusions of technology and capacity. They are perceived as risky since they may exacerbate insecurity of livelihoods by restricting peasants' access to land and natural resources, facilitate environmental degradation, and undermine production for local markets. Von Braun and Meinzen-Dick (2009) elucidate possible benefits to include the creation of significant number of farm and non-farm jobs, poverty-reducing investments such as schools and health centres, as well as enhancements of rural infrastructure. In their view, positive externalities may include new agricultural technologies and practices, as well as increased production and supply of food to local and national consumers, as well as overseas consumers and future global price stability. Others emphasize the threats that the land acquisitions present to rural livelihoods, ecological sustainability and uneven power relations which may further jeopardize local communities' welfare by depriving them of the safety-net function that land fulfills (Peters, 2009). Even those who support large-scale land acquisitions, agree that the perceived benefits will depend on how the investments are implemented, which may, in turn, will depend on the capacity of African governments to hold the investors accountable for their activities in the long term (Odhiambo, 2011).

\section{Policy Support for Land Investments for Better Agricultural Performance}

Access to land for both nationals and foreign investors provides an impetus to the realization of the vision of 
agrarian development. In Central Africa it is enshrined in recent policy documents, e.g. 'Gabon Emergent 2025' or Cameroon's 'Growth and Employment Strategy for 2035' acknowledging the urgency to increase food production and stimulate rural economies. Low levels of domestic agricultural investment will require additional capital and partnership for investors wishing to exploit the sector's potential. The task for governments in the region is therefore not to insulate customary lands, but rather attempt to attract investments that build constructive relationships between local investors, host communities and foreign investors. As Badiane (2012) observes access to land and agrarian investment offers a unique opportunity for sub-Saharan Africa to elevate efforts to sustain its economic recovery and accelerate progress in the fight against poverty.

The context under which governments must be vigilant and encapsulate their efforts is conceptualized in figure 4 which highlights the causal links between prospecting for land resources, the safeguard mechanisms for large-scale land projects, and the attendant effect on environment or livelihoods. The decision-making process is framed into distinct stages which identify key entry points for land property rights management and improving transparency and information disclosure on land deals. The normative schema identifies a hypothetical sequence of events. Key actors involved at each stage play specific roles in terms of facilitating or controlling land acquisition as a viable investment and win-win opportunity for local communities. Paramount is the role of land planning and resource management that regulates land use change and monitors the ensuing outcomes. The inadequacy of land planning may jeopardize the institutionalization of land investments and complicate the distribution of benefits accruing to land exploitation (Assies, 2009; Bell et al., 2006).

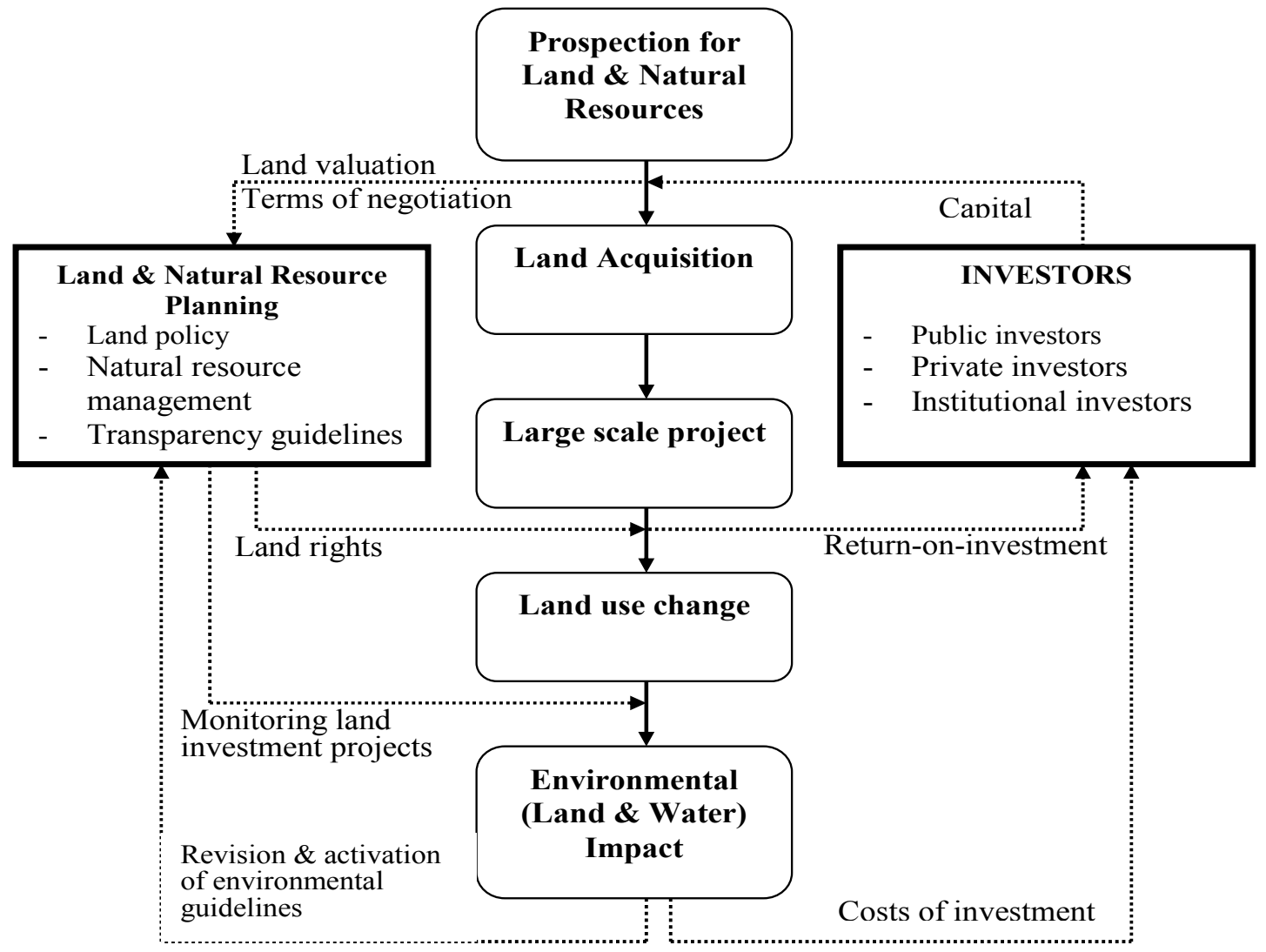

Figure 4. Decision-making in acquisition and allocation of land (Source: Authors' construction)

Whilst Central Africa in particular, or sub-Saharan Africa in general may be too large and diverse to propose a one-size-fits all solution to account for the effect of land acquisition on agrarian progress, some basic and salient conditions need to be met. According to von Braun (2012), properly designed investment on land could incorporate knowledge transfer and institutional strengthening, thus enhancing productivity in targeted countries. However, a combination of government policies, international law, and the involvement of the media, civil society and local communities will be needed to minimize the threats and realize the benefits. In particular, an appropriate code of conduct for host governments and foreign investors intending to acquire land in developing countries should be created in order to include and protect local farmers (see also Borras Jr and Franco 2010; von 
Braun and Meinzen-Dick 2009). This, without doubt, also builds on the African Union guidelines on land policy in Africa as basis for assuring social stability, maintaining economic growth and alleviating poverty, and protecting natural resources from degradation and pollution.

In addition to the FAO, some international stakeholders such as IFAD, the United Nations Conference on Trade and Development (UNCTAD) and the World Bank have agreed over seven principles (RAI, 2010) including policy instruments for responsible agro-investments in relation to land acquisition to include:

$\circ$ Principle 1: Existing rights to land and associated natural resources are recognised and respected.

$\circ$ Principle 2: Investments do not jeopardise food security but rather strengthen it.

- Principle 3: Processes for accessing land and other resources and then making associated investments are transparent, monitored, and ensure accountability by all stakeholders, within a proper business, legal, and regulatory environment.

○ Principle 4: All those materially affected are consulted, and agreements from consultations are recorded and enforced.

o Principle 5: Investors ensure that projects respect the rule of law, reflect industry best practice, are viable economically, and result in durable shared value.

o Principle 6: Investments generate desirable social and distributional impacts and do not increase vulnerability.

$\circ$ Principle 7: Environmental impacts due to a project are quantified and measures taken to encourage sustainable resource use while minimising the risk/magnitude of negative impacts and mitigating them.

In this regard, direct assistance from agencies such as the FAO to developing countries, particularly to the Central African sub-region will have to include:

(a) Documentation and hosting of a data base on land acquisition.

(b) Support the implementation of voluntary guidelines on responsible governance of tenure of land and other natural resources.

(c) Develop guidelines for the consideration of environmental issues in land allocation.

(d) Provide support and advice to the determination of the economic value of land.

(e) Capacity development for strong bargaining power.

(f) Serve as forum for discussion and recommendations on matters pertaining to agricultural land marketing.

\section{Conclusion}

Though Africa is characterized by large amounts of arable land, increasing population and growing industrial base has implied increasing need for fertile arable land to meet food and raw material needs. However, inaccessibility to productive land and threats from competition by large multinationals on fertile land has compounded the agricultural production challenge. What are the lessons for countries in the central African sub-region? Foreign investment on farmland could provide much needed resources for agriculture, including the development of infrastructure and expansion of livelihood opportunities for local people. However, if land-grabbing via large-scale land acquisitions cause land expropriation or unsustainable use, then foreign investments in agricultural land may become politically and economically unsustainable. It would therefore be in the interest of countries in the region to ensure that any arrangements they make on leasing or selling land are properly negotiated, the land-use is sustainable, and the accrued benefits are broad-based.

\section{Acknowledgement}

The authors are grateful to the staff of the Food and Agriculture Organization of the United Nations Sub-regional Office for Central Africa for data collation, and also to the reviewers for helpful comments on earlier versions of this paper. The views expressed in this research are those of the authors and do not necessarily reflect the views or policies of the FAO, or any other organization where the authors work.

\section{References}

African Union Commission. (2010). Framework and Guidelines on Land Policy in Africa. AUC-ECA-AfDB Consortium: Addis Ababa, Ethiopia

Alemu, D. A., \& Scoones, I. (2013). Negotiating new relationships: how the Ethiopian state is involving China 
and Brazil in agriculture and rural development. IDS Bulletin, 44(4), 91-100. http://dx.doi.org/10.1111/1759-5436.12045

Araghi, F. (1995). Global Depeasantization: 1945-1995. The Sociological Quarterly, 36(Spring), 337-368. http://dx.doi.org/10.1111/j.1533-8525.1995.tb00443.x

Arezki, R., Deininger, K., \& Selod, H. (2011). What Drives the "Global Land Rush"? Policy Research Working Paper 5864. Washington, DC: World Bank.

Assies, W. (2009). Land Tenure, Land Law and Development: Some Thoughts on Recent Debates. The Journal of Peasant Studies, 36(3), 573-589. http://dx.doi.org/10.1080/03066150903142824

Badiane, O. (2012). Foreign Direct Investment in Land- And Agriculture-Based Poverty Reduction Strategies In Africa. In: Foreign Direct Investment in Land in West Africa The Status Quo, Lessons from Other Regions, Implications for Research, WCAO Thematic Research Notes. Washington DC: International Food Policy Research Institute.

Bell, K. P., Boyle, K. J., \& Rubin, J. (2006). Economics of Rural Land-Use Change. Aldershot, UK: Ashgate.

Benton, L., \& Straumann, B. (2010). Acquiring Empire by Law: From Roman Doctrine to Early Modern European Practice. Law and History Review, 28, 1-38. http://dx.doi.org/10.1017/S0738248009990022

Bernstein, H. (1996). Agrarian Questions Then and Now. Journal of Peasant Studies, 24(1), 22-59. http://dx.doi.org/10.1080/03066159608438630

Borras Jr, S., \& Franco, J. (2010). From threat to opportunity? Problems with the idea of a "code of conduct" for land-grabbing. Yale Human Rights and Development Law Journal, 13(1), 507-523.

Brautigam, D. (2009). The Dragon's Gift: The Real Story of China in Africa. Oxford: Oxford University Press.

Bräutigam, D., \& Tang, X. (2009). China's engagement in African agriculture: "down to the countryside". China Quarterly, 199, 686-706. http://dx.doi.org/10.1017/S0305741009990166

Cotula, L. (2011). Land Deals In Africa: What Is In The Contracts? IIED, London.

Cotula, L. (2012). The international political economy of the global land rush: a critical appraisal of trends, scale, geography and drivers. Journal of Peasant Studies, 39(4), 649-680. http://dx.doi.org/10.1080/03066150.2012.674940

Cotula, L., \& Vermeulen, S. (2009). 'Land grabs' in Africa: can the deals work for development? Policy Brief. International Institute for Environment and Development (IIED). Retrieved from http://www.iied.org/pubs/display.php?o=17069IIED

Cotula, L., Vermeulen, S., Leonard, R., \& Keeley, J. (2009). Land Grab or Development Opportunity? Agricultural Investment and International Land Deals In Africa, IIED/FAO/IFAD, London/Rome.

Deininger, K. (2011). Challenges posed by the new wave of farmland investment. Journal of Peasant Studies, 38(2), 217-247. http://dx.doi.org/10.1080/03066150.2011.559007

FAO. (2009). From land grab to win-win. Seizing the opportunities of international investment in agriculture. Policy Brief 4, Economic and Social Perspectives, FAO.

FAO. (2012). Global Food Insecurity Report. FAO, Rome.

Friis, C., \& Reenberg, A. (2000). Land Grab in Africa: Emerging land system drivers in a teleconnected world. GLP Report No. 1. GLP-IPO, Copenhagen.

Hofman, I., \& Ho, P. (2012). China's "developmental outsourcing": A critical examination of Chinese global "land grabs" discourse. Journal of Peasant Studies, 39(1), 1-48. http://dx.doi.org/10.1080/03066150.2011.653109

IIED. (2012). Farms and funds: investment funds in the global land rush Policy Brief. The International Institute for Environment and Development (IIED), London.

Jägerskog, A., Cascão, A., Hårsmar, M., \& Kim, K. (2012). Land Acquisitions: How will they Impact Transboundary Waters? Report Nr 30. SIWI, Stockholm.

Kilner, E. (1975). Breadbasket for the Middle East. African Development, 9(1), 9-11.

Lavers, T. (2012). "Land grab" as development strategy? The political economy of agricultural investment in Ethiopia'. Journal of Peasant Studies, 39(1), 105-132. http://dx.doi.org/10.1080/03066150.2011.652091 
Makki, F., \& Geisler, C. (2011). 'Development by Dispossession: Land Grabbing as New Enclosures in Contemporary Ethiopia,' Paper presented at the International Conference on Global Land Grabbing, 6-8 April 2011 Organised by the Land Deals Politics Initiative (LDPI) in collaboration with the Journal of Peasant Studies and hosted by the Future Agricultures Consortium at the Institute of Development Studies, University of Sussex, Sussex, UK.

Matondi, P., Havnevik, K., \& Beyene, A. (2011). Biofuels, Land Grabbing and Food Security in Africa. London and New York, ZED Books.

Miller, C. et al. (2010). Agricultural Investment Funds for Developing Countries. FAO, Rome. Retrieved from http://www.fao.org/fileadmin/user_upload/ags/publications/investment_funds.pdf

Nunow, A. A. (2011). 'The Dynamics of Land Deals in The Tana Delta, Kenya,' Paper presented at the International Conference on Global Land Grabbing, 6-8 April 2011 Organised by the Land Deals Politics Initiative (LDPI) in collaboration with the Journal of Peasant Studies and hosted by the Future Agricultures Consortium at the Institute of Development Studies, University of Sussex, Sussex, UK.

Odhiambo, M. O. (2011). Commercial Pressures on Land in Africa: A Regional Overview of Opportunities, Challenges and Impacts. International Land Coalition.

Peters, P. (2009). Challenges in Land Tenure and Land Reform in Africa: Anthropological Contributions. World Development, 37(8), 1317-1325. http://dx.doi.org/10.1016/j.worlddev.2008.08.021

RAI. (2010). Principles for Responsible Agricultural Investment (RAI) that Respects Rights, Livelihoods and Resources. FAO, IFAD, UNCTAD and World Bank. Retrieved February 20, 2012, from http://www.responsibleagroinvestment.org/rai/node/256

Robertson, B., \& Pinstrup-Anderson, P. (2010). Global Land Acquisition: Neo-Colonialism or Development Opportunity? Food Security, 2, 271-283. http://dx.doi.org/10.1007/s12571-010-0068-1

Tamrat, G. (2010). A Stranger Comes to Town. Fortune, 10(486), 1-5.

UNCTAD (United Nations Conference on Trade and Development). (2008). World Investment Report 2008 Transnational Corporations and the Infrastructure Challenge, Geneva. Retrieved from http://www.unctad.org/Templates/webflyer.asp?docid=10502\&intItemID=4629\&lang=1\&mode=downloads

UNEP (United Nations Environment Programme). (2008). Central Africa and land resources. In C. J. Cleveland (Ed.), Encyclopedia of Earth. Washington, D.C.: Environmental Information Coalition, National Council for Science and the Environment. Retrieved May 4, 2012, from http://www.eoearth.org/article/Central_Africa_and_land_resources?topic $=49516$

von Braun, J. (2012). Policy Implications of Foreign Direct Investment in Africa. In: Foreign Direct Investment in Land in West Africa The Status Quo, Lessons from Other Regions, Implications for Research, WCAO Thematic Research Notes. Washington DC: International Food Policy Research Institute.

Von Braun, J., \& Meinzen-Dick, R. (2009). Land Grabbing by Foreign Investors in Developing Countries: Risks and Opportunities. Policy Brief 13, Washington DC: International Food Policy Research Institute.

World Bank. (2010). Rising Global Interest in Farmland. Washington DC: World Bank.

World Bank. (2011). Food Price Watch. Washington DC: World Bank.

Zoomers, A. (2010). Globalisation and the foreignisation of space: seven processes driving the current global land grab. Journal of Peasant Studies, 37(2), 429-447. http://dx.doi.org/10.1080/03066151003595325

\section{Notes}

Note 1. The FAO Food Price Index is a measure of the monthly change in international prices of a basket of food commodities. The indices Indices show changes in monthly international prices of major food commodities. It consists of the average of five commodity group price indices (representing 55 quotations), weighted with the average export shares of each of the groups for 2002-2004.

Note 2. Other plausible reasons for increasing land needs include: population growth, increasing domestic demand for food, opening of export markets for agriculture, increasing shift to cash crops (such as coffee or cocoa) for exports in order to increase profit per acre, new farm technologies that lower the cost and increase the profitability of farming and lower agricultural transport costs that have resulted in the relative increases in the bid rent for African agriculture. 
Note 3. The assessment involved all countries in Africa and focuses on the deals being made between local governments and foreign investors and countries. Large scale investment lands were broadly defined in this assessment as lands over 1000 ha and contracted or leased mainly for agriculture use. The information gathering processes involved identifying main sources of information, setting parameters and organizing the information obtained in understandable way. The main sources of information were: Books, Magazines and Newspapers, Internet and Media. Available data on the size of land given for foreign investors, host country, name and country of investing company, type of investment, locality and time period was collected. Finally a map was developed to show the distribution, density and location of lands given for the investors.

\section{Copyrights}

Copyright for this article is retained by the author(s), with first publication rights granted to the journal.

This is an open-access article distributed under the terms and conditions of the Creative Commons Attribution license (http://creativecommons.org/licenses/by/3.0/). 